\title{
Tinjauan Komparatif Eksklusivisme Yahudi dengan Pemahaman Keselamatan Orang Kristen Nominal Berdasarkan Yohanes 8: 37-47
}

\author{
Munatar Kause \\ Sekolah Tinggi Agama Kristen Teruna Bhakti, Yogyakarta \\ munatarmoses@gmail.com
}

\begin{abstract}
Leadership is an activity that involves the leaders of where, when, and what he does. In many areas, leadership is a crucial activity advance and retreat of an organization or institution. The same thing happened with the Christian leadership, which is an activity Christian leaders wherever located. In the context of Indonesia's leadership in plural, it takes a complete leader and integrity. A visionary leader, biblical means to have the basics of leadership according to the Bible, which is the word of God which is the handle of a Christian leader.
\end{abstract}

Keywords: biblical, integrity, leadership, visionary

\begin{abstract}
Abstrak: Kepemimpinan merupakan suatu kegiatan yang melibatkan para pemimpin dimana, kapan, dan apa yang dikerjakannya. Dalam berbagai bidang, kepemimpinan adalah suatu kegiatan yang sangat menentukan maju dan mundurnya sebuah organisasi atau lembaga. Hal yang sama juga terjadi dengan kepemimpinan Kristen, yang adalah sebuah kegiatan para pemimpin Kristen dimanapun berada. Dalam konteks kepemimpinan di Indonesia yang pluralis, maka dibutuhkan seorang pemimpin yang lengkap dan berintegritas. Seorang pemimpin yang visoner, alkitabiah artinya memiliki dasar-dasar kepemimpinan yang sesuai dengan Alkitab, yang adalah firman Tuhan yang adalah pegangan seorang pemimpin Kristen.
\end{abstract}

Kata Kunci: alkitabiah, integritas, kepemimpinan, visioner

\section{Pendahuluan}

Panggilan keselamatan dari Allah kepada manusia sejak semula bersifat pribadi. Ketika Adam jatuh ke dalam dosa, Allah datang menjacarinya (Kej. 3:9). Dilanjutkan dengan Abraham yang dipanggil Allah secara pribadi untuk meninggalkan negrinya, sanak saudaranya, dan dari rumah bapanya (Kej. 12: 1-3). Kemudian pada zaman Yesus yang memanggil murid-murid secara pribadi, diantaranya Matius Pemungut cukai (Mat. 9:9). Di kisah Para Rasul, Paulus di panggil Allah secara pribadi (Kis. 9:4-8). Dengan demikian maka keselamatan itu tidak terjadi secara otomatis, tetapi pilihan secara pribadi. Setiap manusia mendapatkan kesempatan untuk selamat, dan hal ini tidak bisa diwakilkan oleh orang lain. Masing-masing pribadi mendapatkan kesempatan untuk menerima Anugerah Allah. John Wesley berkata, "Karya Keselamatan dimulai dengan anugerah pendahuluan 
Allah.” Ini berarti bahwa karya keselamatan Allah tersedia bagi setiap orang, namun setiap pribadi perlu memberikan respon secara pribadi bukan kelompok.

Karena Iman yang memberi keselamatan bukanlah iman kepada sebuah buku, meskipun buku itu Alkitab, bukan iman kepada sebuah kepercayaan, meskipun iman kepercayaan itu ortodoks sekali, bukan iman kepada suatu lembaga, meskipun suatu lembaga itu gereja. Iman yang menyelamatkan adalah iman kepada Tuhan Yesus Kristus. $^{2}$

Iman seseorang tidak bisa mewakili orang lain untuk selamat, karena ini berhubungan dengan keputusan pribadi dari seseorang yang mau untuk diselamatkan. Dalam Alkitab, ada sebuah kisah mengenai seorang kepala penjara di Filipi yang bertobat (Kisah Para Rasul 16:3), dikatakan bahwa " percayalah kepada Tuhan Yesus Kristus dan engkau akan selamat, engkau dan seisi rumah.” Dalam kasus ini bukan berarti iman dari kepala penjara tersebut mewakili seluruh isi rumah tangganya untuk diselamatkan, namun yang dimaksudkan dalam konteks ini adalah keselamatan yang diterima oleh kepala Penjara itu memberi dampak untuk seisi rumah tangganya menjadi percaya kepada Tuhan dan diselamatkan. Millard J. Erickson, dalam pembahasannya mengenai Teologia Kristen Mengatakan bahwa "Keselamatan merupakan karya Kristus terhadap kehidupan seseorang.",3

Keberadaan seseorang yang lahir dari keluarga Kristen sering menjadi alasan dan kebanggaan tersendri bagi orang-orang Kristen nominal sebagai jaminan keselamatan. Dalam hal ini mereka merasa tidak perlu diinjili karena posisi mereka dalam keluarga Kristen menjadi jaminan untuk keselamatan. Tentunya sebuah pemahaman yang keliru, karena tidak satu bagian pun Firman Tuhan yang mendukung ide ini. Dalam Roma 10 : 9, sangat jelas dikatakan bahwa untuk diselamatkan, setiap orang perlu mengaku dengan mulut, bahwa Yesus adalah Tuhan, "sebab dengan hati orang percaya dibenarkan, dan dengan mulut orang mengaku diselamatkan.” J. Clyde Tomer menegaskan bahwa, "orang dapat percaya bahwa Yesus Kristus mati untuk menebus dosanya, tetapi ia akan mati dalam dosanya jikalau ia tidak menerima Kristus sebagai juruselamatnya sendiri."4

Kenyataannya bahwa kebanyakan orang-orang Kristen nominal, terutama di daerahdaerah yang mayoritas Kristen, dalam praktek hidup sehari-hari hidup tidak sesuai dengan kehidupan Kristen yang sesungguhnya, bahkan tidak semua orang yang Kristen itu merasa yakin akan keselamatannya. Dalam hal ini, Murray W. Downey, berkata: Orang yang mengaku Kristen tetapi masih terus melakukan dosa, hendaknya yakin bahwa ia tidak diselamatkan. Jika apa yang dipercayai seseorang tidak memengaruhi perbuatanya, maka

\footnotetext{
${ }^{1}$ Loveth H. Weems, JR, Pesan John Wesley Masa Kini, (Medan: Gereja Methodist Indonesia, 1977), 25 .

${ }^{2}$ J. Clyde Tumer, pokok - pokok Kepercayaan Orang Kristen (Bandung: Lembaga Literatus Baptis, 1978), 114.

${ }^{3}$ Millard J. Erickson, Teologia Kristen, Volume Tiga, (Malang :Gandum Mas,2004), 69.

${ }^{4}$ Ibid., 115
} 
imannya sia-sia. ${ }^{5}$ Mereka hanya merasa bangga dengan posisinya sebagai orang Kristen karena faktor keturunan, dan bukan karena mereka telah menerima Yesus sebagai Tuhan dan juruselamat secara pribadi.

Pemahaman mengenai keselamatan dalam orang Kristen Nominal tidak jauh berbeda dengan sikap orang-orang Yahudi pada zaman Yesus. Dalam Yohanes 8:37 - 47, terjadi perdebatan antara Yesus dengan orang-orang Yahudi yang merasa eksklusif dengan posisi mereka sebagai keturunan Abraham. Pada ayat 39 dalam teks ini mereka berkata bahwa " bapa kami adalah Abraham. "Abraham menjadi begitu penting bagi mereka, ini menjelaskan kepercayaan umum tentang jasa-jasa besar dari Abraham yang dinggap tersedia bagi kebutuhan keturunannya."6 Kenyataannya yang Yesus lihat pada mereka sangatlah berbeda dengan Abraham. Disini Yesus mengecam mereka dengan berkata "jikalau sekiranya kamu anak-anak Abraham, tentulah kamu mengerjakan pekerjaan yang dikerjakan oleh Abraham," (ayat 39). Anak-anak Abraham seharusnya mampu menghasilkan perilaku seperti Abraham, dia bertindak mengikuti Firman Tuhan tanpa memberontak terhadap Allah. Tapi kenyataannya disini mereka malah berusaha membunuh Yesus yang sedang memberitakan kebenaran Allah yang dipercayai oleh Abraham bapa leluhur mereka.

Sikap orang-orang Yahudi yang merasa "Eksklusif” karena keturunan dari Abraham menyebabkan mereka menolak Yesus, sehingga mereka juga tidak menerima anugerah keselamatan dari Allah melalui Yesus Kristus. Demikian juga dalam kehidupan Kristen Nominal, mereka hanya merasa cukup dan bangga sebagai orang yang lahir dari keturunan Kristen untuk selamat, tanpa harus menerima Yesus sebagai Tuhan dan Juruselamat mereka yang disertai dengan pertobatan.

Dengan demikian mereka perlu sebuah pengajaran untuk menolong mereka dari pemahaman yang keliru tentang keselamatan, Sebab:

Halnya seperti seorang ayah yang memberikan anak-anaknya sebuah ladang. Ladangnya diperoleh tanpa biaya, karena diberi oleh ayahnya. Tetapi apa yang akan keluar dari ladang itu, bergantung kepada apa yang ditaruh didalamnya. Jika dilalaikannya, akan tumbuhlah lalang dan rumput, dan tidak akan menghasilkan panen. $^{7}$

\section{Eksklusivisme Yahudi}

Eksklusivisme Yahudi dan Kristen Nominal adalah dua hal yang berbeda, namun dalam hal iman dan keselamatan kedua bagian ini memiliki kesamaan atau ada titik temu antara kedua hal ini. Dengan demikian, maka bagian ini akan menjelaskan tentang perbandingan Eksklusivisme Yahudi dengan Kristen nominal. Eksklusivisme Yahudi

\footnotetext{
${ }^{5}$ Murray W. Downey, Cara-cara Memenagkan Jiwa,(Bandung: Kalam Hidup, 1975), 31.

${ }^{6}$ Donald Guthrie, Tafsiran Alkitab Masa Kini3 Maitus-Wahyu, (Jakarta: BPK Gunung Mulia, 1982), 308.

${ }^{7}$ J. Clyde Tumer, pokok - pokok Kepercayaan orang Kristen (Bandung: Lembaga Literatur Baptis, 1978), 119
} 
adalah satu hal yang menunjukan keistimewaan yang tidak ada pada bangsa lain. Dalam hal ini berkaitan dengan latarbelakang dari bangsa Yahudi itu sendiri. Mengapa mereka dianggap "eksklusif” atau mengapa mereka merasa eksklusif?

Keberadaan bangsa Yahudi tidak terlepas dari seorang tokoh yang bernama Abraham, yang di dalam Alkitab disebut sebagai bapa orang beriman atau bapak orang percaya. Abraham sebagai leluhur dari bangsa Yahudi memiliki kedudukan yang istimewa dan sangat mempengaruhi keyakinan dari bangsa Yahudi. Menurut Michael Keene, Sejarah bangsa Yahudi dimulai dengan Abraham yang mendengarkan panggilan Allah untuk menduduki tanah Kanaan."8 Alkitab, khususnya dalam kitab Kejadian, memberitahukan bahwa dari Abraham Lahirlah Ishak, kemudian dari Ishak lahirlah Yakub dan dari Yakub lahir 12 anak-anak yang kemudian menjadi kedua belas suku Israel.

Seruan mereka kepada Allah didengar, sehingga munculah seorang yang dipakai Allah untuk membesakan mereka dari perbudakan di Mesir. Musa mendengar suara Allah yang berbicara kepadanya dari suatu semak yang menyala tetapi tidak terbakar dan, atas perintahNya, Musa pergi ke Firaun yang kala itu sebagai pemimpin bangsa Mesir, untuk meminta supaya bangsa Israel dibebaskan. Hanya karena 10 wabah dari Allah menimpa orang-orang Mesisr maka permintaan itu dikabulkan ( Kel.2:23-11:9). Michael Keene menjelaskan bahwa:

Kemudian bangsa Israel menghabiskan waktu selama 40 tahun dalam perjalanannya sebagai kaum pengembara sebelum mereka tiba tanah terjanji. Selama perjalanan mereka itu - keluaran - Allah memberikan sepuluh perintah kepada Musa di gunung Sinai. Bangsa Yahudi juga diberi banyak hukum yang lain untuk mengurus semua aspek kehidupan pribadi serta masyarakat dan hukum-hukum ini masih berpengaruh pada kehidupan orang-orang Yahudi sampai sekarang. ${ }^{9}$

Dalam sejarah perjalanan Isreal, Allah memimpin mereka dengan luar biasa sampai tanah perjanjian menjadikan mereka sebagai satu-satunya bangsa yang menyembah kepada Allah yang benar. Pengalaman mereka bersama dengan Allah dalam berbagai hal menyebabkan mereka menjadi umat yang khusus dan berbeda dari bangsa-bangsa yang lain di sekitar mereka. Bahkan mereka disebut sebagai umat Pilihan Allah atau kepunyaan Allah, umat perjanjian, anak-anak Allah. Walter C. Kaiser, Jr. mengatakan:

Israel bukan sekedar kelauarga atau anak Allah; Israel juga telah menjadi goy,suatu "bangsa" (Kel 19:6). Kenyataan ini pertama kali menjadi jelas ketika Tuhan berfirman kepada Musa di dalam semak yang menyala, "Aku telah memperhatikan dengan sunguh kesengsaraan umatKu di tanah Mesir" (Kel3:7). Sebutan ini diulangi oleh Musa kepada Firaun dalam permintaan pasti Allah: "Biarkanlah umat-Ku pergi” (Kel5:1;7:14;8:1,20;9:1;10:3). Disebit "umat" ('am) berarti bahwa mereka adalah suatu keompok sosial etnik dengan kekuatan yang cukup dan kesatuan yang cukup untuk dipandang sebagai suatu keutuhan kelompok. Sekalipun demikian mereka begitu erat terkait dengan Yahwe sehingga Ia menyebut mereka 'Umat-Ku'10 .

\footnotetext{
${ }^{8}$ Michael Keene. Agama-agama Dunia (Yogyakarta: Kanisius, 2006), 40.

${ }^{9}$ Michael Keene., 40

${ }^{10}$ Walter C. Kaiser, Jr., 138
} 
Dari situlah bangsa Israel merasa Eksklusif sebagai Keturunan Abraham yang dipilih Allah Umat kepunyaan Allah yang dipelihara secara khusus daripada bangsa-bangsa lain, dan sepertinya merekalah yang paling berkenan dihadapan Allah dan bangsa yang lain tidak.

\section{Tradisi Yahudi}

Dalam sejarah Israel, mereka sangat memegang tradisi yang sudah diturunkan oleh nenekmoyang mereka. Tradisi-tradisi secara lahiriah sangat dipertahankan secara turun temurun, setiap orang wajib untuk melakukan tradisi-tradisi atau berusaha untuk menolaknya maka akan ada sangsi sosial yang akan di terimanya. Hal ini sangat jelas terlihat pada zaman Yesus, dimana mereka sangat membenci Yesus ketika Yesus menyembuhkan orang sakit pada hari sabat. Hal ini menurut tradisi Yahudi bertentangan, sehingga mereka berusaha untuk melakukan perlawanan terhadap tindakan Yesus (Lukas 6:6-11). Tradisi-tradisi tersebut seperti: Hukum Taurat, Hari Sabat, Paskah, dan Sunat.

Bagi orang Yahudi yang saleh, Taurat merupakan pusat kehidupan, hal ini sudah dianut oleh mereka dari waktu kewaktu sampai hari ini. Orang-orang yang melanggar hukum taurat akan menerima sangsi yang cuku besar. "Taurat" artinya "hukum" atau "pengajaran" dan menunjuk pada keseluruhan apa yang diketahui tentang Allah dan hubunganNya dengan dunia ciptaanNya."11 Selain itu juga, dalam pengertian yang lebih sempit, "Taurat menunjuka pada lima kitab Musa - Kejadian, Keluaran, Imamat, Bilangan, dan Ulangan- yang terletak di permulaan Kitan Suci." ${ }^{12}$ Taurat sangat di hargai dan dihormati dalam kehidupan Yahudi, bahkan orang-orang yang melanggar taurat akan menerima hukuman yang sangat berat. "Taurat dirayakan sebagai pemberian Tuhan terbesar kepada orang-orang Yahudi."13

Bagian penting ibadat umat Yahudi adalah pembacaan Taurat dengan suara keras sejumlah ayat dari taurat. "Di sinagoga, bacaan dari gulungan Kitab Taurat, atau sefer Torah, dibacakan pada hari Sabat pagi dan Sore, perayaan keagamaan pagi, dan pada hari senin dan Selasa pagi." ${ }^{14}$ Hal itu dilakukan sebagai bentuk penghormatan terhadap Taurat. Bahkan bentuk penghormatan itu dianjurkan juga dalam hal siapakah yang boleh membukanya. "Kitab Taurat hanya boleh dibuka oleh orang laki-laki, demikian dalam tradisi Ortodoks, dan untuk dibacakan di depan umat. Orang yang ditunjuk untuk membaca Kitab Suci dalam bahasa Ibrani harus menggunakan Yad-alat penunjuk yang dipegang." 15

Salah satu contoh kepentingan Taurat bagi orang-orang Yahudi dalam kehidupan sehari-hari adalah terlihat dalam "Buku Doa Yahudi" yaitu:

Engkau mengajar umat-Mu dengan Taurat dan perintah-perintahMu; Engkau memerintah umat-Mu dengan hukum-hukumMu dan dengan kedialan-Mu, $\mathrm{O}$ Allah

\footnotetext{
${ }^{11}$ Michael Keene, 44.

${ }^{12}$ Ibid.

${ }^{13}$ Ibid.

${ }^{14}$ Ibid.

${ }^{15}$ Ibid.
} 
kami, jika kami tidur seperti kami bangun, kami akan selalu memikirkan dan mengatakan tentang undang-undang-Mu dan kegembiraan yang ada di dalam Taurat dan perintah-perintah-Mu. Karena Tuarat-Mu kami mampu bertahan hidup; dengan pengajaran-pengajarannya kami akan melakukan meditasi siang dan malam. ${ }^{16}$

Berikutnya adalah tentang hari Sabat, hari di mana dalam seminggu digunakan untuk beristirahat; dimulai pada hari Jumat saat matahari terbenam sampai dengan hari sabtu senja. Kitab suci Yahudi mengatakan bahwa seluruh orang Yahudi harus rajin menjaga kemurnian hari Sabat karena: "Allah sendiri beristirahat pada hari ketujuh setelah penciptaan dunia." 17 Selain itu, alasan lain mengapa harus menjaga hari sabat adalah karena : "setelah bangsa Yahudi keluar dari perbudakan di Mesir, Allah menyediakan hari Sabat supaya pada hari itu semua orang, termasuk budak-budak dan juga binatang, tidak melakukan pekerjaan apapun." ${ }^{18}$ Hari sabat juga merupakan puncak perayaan bagi kehidupan bangsa Yahudi, karena hal itu menjadi peringatan mingguan bagi seluruh bangsa Yahudi akan penciptaan kehidupan dan perjanjian yang dibuat dengan Allah.

Menurut hukum tradisional Yahudi, dan berdasarkan petunjuk para rabi masa lalu, pada hari sabat melarang melakukan sagala pekerjaan. Dikatakan:

Pada hari itu melarang melakukan segala pekerjaan dalam hal ini diinterprestasikan oleh orang-orang Yahudi yang taat beribadat sebagai segala kegiatan bisnis, menggunakan uang, berbelanja, mengerjakan pekerjaan rumah tangga, dan menggunakan segala jenis alat transportasi, listrik, dan bahkan telpon. ${ }^{19}$

Dengan demikian maka otomatis pada hari sabat tidak boleh melakukan satu kegiatan apapun, keculai beribadah sambil membaca Taurat. Keene, menambahkan bahwa:

Pada hari Sabat pagi, seluruh keluarga hadir di sinagoge. Dalam ibadat, tujuh umat dipersilahkan menuju bimah untuk menyertai pembaca yang membacakan ayat-ayat tertentu dari Taurat dan mengucapkan doa syukur kepada Allah atas anugerah-Nya untuk hari yang istimewa ini. Seorang yang lain kemudian membaca perikop dari Kitab Nabi-nabi. Ibadat diakhiri dengan khotbah berdasarkan Taurat. ${ }^{20}$

Dalam tradisi Yahudi, umat Yahudi memakai upacara sunat bersama-sama dengan Islam, walaupun dilaksanakan dengan alasan-alasan yang berbeda-beda. "Tradisi sunat ini biasanya dilakukan kepada setiap anak laki-laki Yahudi, Sunat, atau brit milah, untuk anak laki-laki yang sudah berusia delapan hari." ${ }^{21}$ Tradisi Sunat masih dilakukan sampai sekarang, tradisi ini dimulai oleh Abraham sebagai tanda perjanjiannya dengan Allah, namun sunat bukalah merupakan suatu tanda bukti beriman dalam Yahudi, tetapi sunat dilakukan sebagai tanda jasmani bagi anak laki-laki yang mengambil bagian dalam mengadakan perjanjiannya dengan Allah untuk selamanya.

\footnotetext{
${ }^{16}$ Ibid.

${ }^{17}$ Ibid.

${ }^{18}$ Ibid.

${ }^{19}$ Ibid.

${ }^{20}$ Ibid

${ }^{21}$ Ibid., 54
} 
Menurut tradisi, sunat biasanya dilakukan oleh ayah dari si anak, tetapi pada zaman sekarang hal ini dilakukan oleh seseorang ahli sunat yang sudah dilatih. Ahli yang melakukan sunat di sebut mobel, biasanya dilakukan di rumah anak itu atau di sinagoga. Keene, menjelaskan:

Tradisi Ortodoks memanggil 10 anak laki-laki suaya hadir ketika upacar sunat dilaksanakan. Ibu wali menghadirkan anak itu di antara anak-anak yang diundang, di mana ia dipegang oleh bapak wali, dan sesaui tradisi ibu anak itu sendiri tidak hadir. Setelah upacara selesai, anak itu diberi nama lalu disusul dengan menuangkan setetes anggur pada bibir anak itu. Ayah lalu meminum sisa anggurnya. Segenap keluarga berdoa supaya anak itu tumbuh dan mengasihi Tuhan, mempelajari Taurat dan hidup dengan baik. ${ }^{22}$

Biasanya bapak dari anak yang di sunat, akan mengucapkan kata-kata berkat bagi anak itu sebagai doa. Ucapan berkat dari bapak itu adalah seperti : "Terpujilah Engkau, ya Tuhan Allah kami, yang berkuasa atas roh jagad raya, yang telah memerintah kami untuk ikut dalam perjanjian leluhur kami, Bapak Abraham." 23

\section{Orang Kristen Nominal}

Kristen Nominal adalah sekelompok orang yang beragama Kristen tetapi berdasarkan tradisi bukan melalui sebuah kepercayaan secara pribadi. Kata "nominal" berarti: 1. hanya namanya, 2.menurut yang tercatat atau apa yang tertulis saja. ${ }^{24}$ Sedangkan Kristen adalah "nama agama yang disampaikan oleh Kristus (Nabi Isa)." ${ }^{25}$ Dalam pengertian kedua istilah ini, maka definisi Kristen Nominal adalah penganut agama Kristen yang tercatat secara identitas, namun bukan pengikut atau orang yang sungguh-sungguh beriman kepada Yesus sebagai Tuhan dan Juruselamat. Golongan ini hanya menganut agama Kristen tetapi tidak hidup dalam ajaran Kristen.

Penjelasan yang sama mengenai orang Kristen nominal dari sebuah data di artikel dalam situs internet. Menjelaskan bahwa:

Para Rasul dan orang Kristen mula-mula begitu menderita. Namun hari ini sangat sedikit orang injili yang mau menderita bagi Kristus di Amerika dan Eropa. Mengapa? Jawabannya sederhana saja - banyak orang injili hanyalah orang-orang Kristen KTP (nominal) saja. Kamus mengartikan "nominal" (bahasa Inggris) sebagai "hanya namanya, bukan faktanya," bukan dalam realitasnya (catatan dari Dr. Purwanto, Kristen "nominal" yang dimaksud di sini sama dengan orang Kristen di Indonesia yang kita sebut Kristen KTP atau Kristen Tanpa Pertobatan). ${ }^{26}$

Dengan demikian berarti bahwa, orang Kristen nominal itu ada. Hal ini dapat dibuktikan oleh sebuah penelitian yang memberikan penjelasan mengenai keberadaan orang Kristen nominal di dunia. "Orang Kristen nominal berjumlah 1,3 milyar yang mengaku Kristen namun tidak aktif dalam iman mereka. Mereka telah dibaptis, menghadiri gereja beberapa

\footnotetext{
${ }^{22}$ Ibid., 54-55.

${ }^{23}$ Ibid. hal 55

${ }^{24}$ J Poerwadarminta, Kamus Besar Bahasa Indonesia, ( Jakarta: Balai Pustaka, 1983), 616

25 Ibid, 465

26 www.persecution.com.
} 
kali, menyebut diri orang Kristen namun soal komitmen pribadinya kepada Kristus merupakan hal yang asing bagi mereka.,"27

Orang Kristen nominal, kelihatannya mengiring Tuhan, tetapi tidak mengalami kemajuan iman. Kehidupan mereka masih dalam kedagingan sehingga tidak sehingga tidak menjadi berkat bagi sesamanya. Dalam buku Model-Model Penginjilan Yesus, dikatakan bahwa orang Kristen nominal:

Mengikuti Yesus dengan paradigma yang salah. Persoalan yang telah dijumpai dalam kehidupan orang-orang Kristen nominal ini adalah bahwa mereka masih mengandalkan paradigma yang . pandangan hidup yang berdosa masih tidak mereka buang. Pertobatan mereka adalah pertobatan yang semu. Mereka hanya menjadi orang-orang Kristen tradisi. ${ }^{28}$

Kristen nominal adalah orang-orang yang pada umunya lahir dari keluarga Kristen, dan tanpa melalui sebuah penginjilan, mereka sudah menjadi orang yang beragama Kristen oleh karena lahir dari keluarga Kristen secara turun-temurun. Sehingga yang terjadi adalah mereka hanya memiliki identitas agama Kristen tapi tidak melakukan ajaran-ajaran Kristen dengan baik, bahkan hidup bertolak belakang dari Firman Allah.

Dalam berbagai kasus, rupa-rupanya mereka banyak berasal dari Kristen keturunan, karena keluarga mereka Kristen, maka mereka juga ikut menjadi Kristen. Akibatnya pertobatan dan pengenalan mereka sangat dangkal. Mereka masih hidup dalam perhambaan dosa dan masih membutuhkan kemerdekaan Kristus. ${ }^{29}$ "Pengenenalan mereka akan Kristus begitu jaug sehingga mereka justru tidak mengerti anugerah dan iman."

Keberadaan orang Kristen nominal sebenarnya bukanlah hal yang baru dalam lingkungan orang percaya atau gereja masa kini. Jika mengacu kepada arti dari Kristen nominal, maka keberadaannya sudah ada sejak zaman Yesus, Para Rasul, dan Jemaat mulamula sudah ada pribadi-pribadi yang demikian. Hal tersebut dapat terlihat dari teks-teks yang mengungkapkannya secara tidak langsung seperti: Matius 13:24-30, 36-43; Yohanes 15:1-7; Yohanes 6:70-71; Matius 7:15-23; 1Yohanes 2:18-19; 2 Petrus 2:1-3; Ibrani 6:4-6; Yudas 4, 12; Yakobus 2:17-20; Wahyu 3:1; II Timotius 3:5.

\section{Metodologi}

Artikel ini menggunakan pendekatan kualitatif dengan menggunakan metode analisis teks pada Yohanes 8:37-47. Ada dua tahapan pendekatan dalam proses ini yaitu dengan memperhatikan teks secara gramatikal dan literal. Nas tersebut dalam Alkitab Terjemahan Baru (Lembaga Alkitab Indonesia) adalah sebagai berikut:

${ }^{37}$ Aku tahu, bahwa kamu adalah keturunan Abraham, tetapi kamu berusaha untuk membunuh Aku karena firman-Ku tidak beroleh tempat di dalam kamu. ${ }^{38}$ Apa yang

\footnotetext{
${ }^{27}$ Robby \& Jackie Butler, Be A Part Of It, ( US Center For World Mission, 1996).

${ }^{28}$ Makmur Halim. Model-model Penginjilan Yesus ( Malang: Gandum Mas, 2003), 535

${ }^{29}$ Frans Paillin Rumbi, “Tradisi Massuru ' Dan Pertobatan Dalam Injil Sinoptik,” BIA: Jurnal Teologi dan Pendidikan Kristen Kontekstual 1, no. 1 (2018): 26-38, http://www.jurnalbia.com/index.php/bia.
} 
Kulihat pada Bapa, itulah yang Kukatakan, dan demikian juga kamu perbuat tentang apa yang kamu dengar dari bapamu." ${ }^{39}$ Jawab mereka kepada-Nya: "Bapa kami ialah Abraham." Kata Yesus kepada mereka: "Jikalau sekiranya kamu anak-anak Abraham, tentulah kamu mengerjakan pekerjaan yang dikerjakan oleh Abraham. ${ }^{40}$ Tetapi yang kamu kerjakan ialah berusaha membunuh Aku; Aku, seorang yang mengatakan kebenaran kepadamu, yaitu kebenaran yang Kudengar dari Allah; pekerjaan yang demikian tidak dikerjakan oleh Abraham. ${ }^{41}$ Kamu mengerjakan pekerjaan bapamu sendiri." Jawab mereka: "Kami tidak dilahirkan dari zinah. Bapa kami satu, yaitu Allah." ${ }^{42}$ Kata Yesus kepada mereka: "Jikalau Allah adalah Bapamu, kamu akan mengasihi Aku, sebab Aku keluar dan datang dari Allah. Dan Aku datang bukan atas kehendak-Ku sendiri, melainkan Dialah yang mengutus Aku. ${ }^{43}$ Apakah sebabnya kamu tidak mengerti bahasa-Ku? Sebab kamu tidak dapat menangkap firman-Ku. ${ }^{44}$ Iblislah yang menjadi bapamu dan kamu ingin melakukan keinginan-keinginan bapamu. Ia adalah pembunuh manusia sejak semula dan tidak hidup dalam kebenaran, sebab di dalam dia tidak ada kebenaran. Apabila ia berkata dusta, ia berkata atas kehendaknya sendiri, sebab ia adalah pendusta dan bapa segala dusta. ${ }^{45}$ Tetapi karena Aku mengatakan kebenaran kepadamu, kamu tidak percaya kepadaKu. ${ }^{46}$ Siapakah di antaramu yang membuktikan bahwa Aku berbuat dosa? Apabila $\mathrm{Aku}$ mengatakan kebenaran, mengapakah kamu tidak percaya kepada-Ku? ${ }^{47}$ Barangsiapa berasal dari Allah, ia mendengarkan firman Allah; itulah sebabnya kamu tidak mendengarkannya, karena kamu tidak berasal dari Allah.

\section{Pembahasan}

\section{Pendekatan Gramatikal}

Secara hukum srtuktur Hermeneutika, ayat - ayat pada nas tersebut terdapat beberapa hal yaitu: hukum sebab akibat, kontras, pengulangan, subyek/obyek, peningkatan pikiran dan klimaks. Demikian juga untuk mengerti kalimat yang terdapat dalam teks pembahasan ini, maka tata bahasa perlu diperhatikan untuk mengerti makna yang terkandung di dalamnya.

Ayat 37, merupakan lanjutan dari pernytaan Yesus dari ayat-ayat sebelumnya mengenai pernyataan orang-orang Yahudi yang mengatakan bahwa kami adalah keturunan dari Abraham (ayat 33). Pernyataan Yesus “Aku tahu bahwa kamu adalah keturunam Abaraham, tetapi kamu berusaha untuk membunuh Aku karena firman-Ku tidak beroleh tempat di dalam kamu..." Frasa "Aku tahu," yang dimaksudkan sebagai subyeknya adalah Yesus sendiri. Frase ini mengacu kepada pernyataan-pernyataan sebelumnya dari obyek lawan bicara dari Tuhan Yesus yaitu "kamu" orangYahudi. Ide penghubung dalam ayat ini adalah " bahwa," kata ini dalam bahsa Yunani adalah ö ı (hoti).

Dalam kasus tertentu, kata ini menandakan suatu percakapan langsung, sehingga ia dapat diterjemahkan dengan tanda baca (,). ${ }^{31}$ Dalam kasus tersebut kata ini adalah kata penghubungan, yang menentukan adanya hubungan antara kalimat pokok dan anak kalimat. Dalam teks di ayat ini induk kalimatanya adalah "keturunan Abraham" dan anak kalimatanya adalah "Aku tahu." Dalam teks ini, Yesus mengakui orang Yahudi sebagai keturunan Abraham. walaupun demikian, kenyataan yang Yesus lihat pada orang Yahudi

\footnotetext{
${ }^{31}$ Sutanto, Interliniar Perjanjian Baru., 584.
} 
adalah sangat kontras dengan Abraham nenek moyang mereka, memang mereka adalah keturunan Abraham,"tetapi" mereka berusaha membunuh Yesus. Kata "tetapi" dalam bahasa Yunani adalah “ $\alpha$ ' $\lambda \lambda \alpha$ ” (alla). Kata ini merupakan kata penghubung yang mengkontraskan, juga dipakai bentuk coordonating (adanya hubungan yang setara namun membawa dampak dalam hal ini adalah mereka berusahan membunuh Yesus). Selanjutnya Yesus mengatakan sebab akibat dari tindakan orang Yahudi yaitu '"karena firman-Ku tidak beroleh tempat di dalam kamu." Tentunya hal ini berbeda dengan Abraham yang adalah seorang yang taat. Dalam tafsiran The Wycliffe Bible Commentary, dijelaskan bahwa tetapi perlawanan mereka terhadap diri-Nya menunjukan bahwa secara rohani mereka bukan keturunan Abraham, yang adalah seorang yang penuh iman dan taat. ${ }^{32}$ Kenyataannya adalah orang Yahudi tidak seperti Abraham, ini dilihat dari kata "tetapi" menandakan adanya perbedaan, tindakan mereka dengan Abraham yang merupakan nenek moyang mereka, sebab akibatnya dalam mereka tidak memberikan tempat untuk Firman yang disampaikan oleh Yesus.

Ayat 38 Yesus berkata "Apa yang Kulihat pada Bapa, itulah yang Kukatakan, dan demikian juga kamu perbuat tentang apa yang kamu dengar dari bapamu." Dalam ayat ini Yesus memberitahukan alasan mengapa mereka harus mendengar dan menerima Firman yang disampaikan. Yesus berkata "Apa yang Kulihat "pada” Bapa. Kata "pada” dalam teks Yunani $\pi \alpha \rho \alpha$ (para) merupakan preposisi dengan kasus datif yang adalah kata depan yang digunakan untuk menunjukan kepada posisi tertentu.dalam hal ini mengarah kepada Alla Bapa yang mengutus Yesus. Ia membandingkannya dengan tindakan orang Yahudi,"dan demikian juga kamu perbuat apa yang kamu denngar dari bapamu." Secara literal dalam ayat ini, Yesus menhubungkan kalimat apa yang dilihat dan dikatakan itu bersal dar satu pribadi yaitu Bapa, ini juga menunjukan hukum peningkatan pikiran.

Ayat 39 mengatakan bahwa "Jawab mereka kepada-Nya: "Bapa kami ialah Abraham." Kata Yesus kepada mereka: "Jikalau sekiranya kamu anak-anak Abraham, tentulah kamu mengerjakan pekerjaan yang dikerjakan oleh Abraham". Ketika Yesus menyampaikan bahwa apa yang dikatakanNya itu berasal dar Bapa, (Allah yang orang Yahudi ketahui), kembali lagi orang Yahudi berpatokan kepada Abraham. mereka berkata

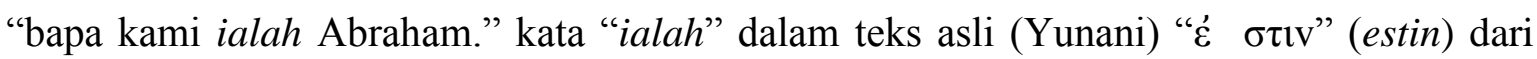
kata $\epsilon \iota \mu$ ( $(\text { eimi })^{33}$ yang berarti “ialah." Kata ini merupakan penjelasan yang mengarah kepada pribadi, dengan bentuk orang ketiga tunggal.

Dalam teks ini berarti kembali menekankan tentang keberadaan mereka sebagai keturunan Abraham. Yesus merespon perktaan mereka dengan berkata "jika." Kata ini merupakan sebuah penghubung yang mengarah kepada suatu keadaan namun menunjukan kepada sebuah persyaratan. Dikatakan "jikalau sekiranya kamu anak-anak Abraham,

\footnotetext{
${ }^{32}$ The Wycliffe Bible Commentary, 338.

${ }^{33}$ Hasan Sutanto.Interlinear., 244.
} 
tentulah..." Jadi keadaan yang Yesus lihat tidak seperti atau kontras dengan Abraham nenek moyang (Bapa) orang Yahudi. Dalam buku Tafsiran Masa Kini, menyatakan:

Demikian pentingnya bagi mereka hubungan dengan Abraham, sehingga mereka tak dapat luput dari padanya. Ini menjelaskan kepercayaan umum tentang jasa-jasa besar dari Abraham, dianggap tersedia bagi keturunannya. Tapi Yesus mengoreksi kesalahpahaman umum itu dengan menentang dasarnya. Rumusan penentuan anakanak Abraham haruslah berdasarkan moral, bukan berdasarkan keturunan jasmani. ${ }^{34}$

Ide kontras kembali dikemukakan oleh Yesus dalam ayat 40. Yaitu Yesus berkata " tetapi yang kamu kerjakan ialah beruasaha membunuh aku..." Kata "tetapi" penghubung yang masih menghubungkan kalimat ayat ayat sebelumnya yaitu ayat 39 dengan memakai bentuk coordinating-adversativ. Yang berarti memiliki ide yang sama dengan ayat sebelumnya, bahwa adanya hubungan antara induk kalimat dalam ayat 39 "anak Abraham" dengan anak kalimat dalam ayat 40. Ayat 37 menyatakan "berusaha membunuh Aku", ayat 40 juga mengulang kembali kalimat ini. Dia pribadi yang mengatakan kebenaran yang berasal dari Bapa dan ini merupakan pekerjaan-Nya. Dipakai kata dari, bahasa aslinya memakai $\pi \alpha \rho \alpha$ berarti kata sambung dengan kasus genetif.

Tindakan mereka terhadap Yesus bukanlah teladan dari Abraham. dalam hal ini William Barclay, mengatakan "didalam bagian ini Yesus memberikan suatu pukulan yang mematikan atas suatu tuntutan yang dipandang oleh orang-orang Yahudi maha penting. Bagi orang Yahudi Abraham adalah tokoh yang terbesar di dalam sejarah keagamaan. ${ }^{35}$ Ditemukan kembali penggunaan kata dari dalam ayat 41 " Kami tidak dilahirkan dari zinah," bentuk kata dari atau $\varepsilon \kappa$ memberikan fungsi kepada kata sesudahnya sehingga dikatakan dari zinah bahkan dilanjkutkan dengan mengarah kepada kalimat yang mengalami peningkatan "Bapa kami satu, yaitu Allah."

Ayat 42 merupakan jawaban Yesus kepada mereka " Jikalau Allah adalah Bapamu, kamu akan mengasihi Aku, sebab Aku keluar dan datang dari Allah. Kata jikalau " $\varepsilon$ " memakai sifat conditional menunjukkan kepada suatu keadaan, hal ini juga telah dibahas dalam ayat sebelumnya. Di mana kata selanjutnya dalam ayat ini Allah adalah Bapamu, menegaskan bahwa adanya hubungan yang sangat dekat seperti seorang ayah dan anaknya. Kalimat seterusnya menggambarkan adanya hubungan sebab-akibat, terlihat dari kalimat, sebab Aku keluar dan datang dari Allah. Yesus mengungkapkan hal itu kepada mereka bahwasanya Yesus yang berasal dari Bapa bahkan diutus oleh Bapa sendiri, mengapa mereka tidak mengasihi Yesus sementara mereka mengaku bahwa Allah adalah Bapa mereka. Ungkapan dalam ayat 43 juga mengarah kepada hubungan sebab-akibat, “ Apakah sebabnya kamu tidak mengerti bahasa-Ku?" Sebab kamu tidak dapat menangkap firman$\mathrm{Ku}$. Karena mereka tidak bisa menangkap firman yang Yesus sampaikan sehingga mereka tidak bisa mengerti bahasa Yesus.

\footnotetext{
${ }^{34}$ Tafsiran Masa Kini., 296.

${ }^{35}$ William Barclay. Pemahaman Alkitab Setiap Hari Injil Yohanes (Jakarta: BPK Gunung Mulia, 2003), 39.
} 
Yesus langsung memepertegas perkataanNya (44) kepada mereka "Iblislah yang menjadi bapamu dan $(\kappa \alpha \imath)$ menandakan hubungan yang setara dengan kelimat sesudahnya "kamu ingin melakukan keinginan-keinginan bapamu. Kalimat selanjutnya mengalami peningkatan ia adalah pembunuh...dan tidak hidup dalam kebenaran (hubungan yang setara) sebab, kembali menunjukkan hubungan sebab akibat, karena didalam iblis tidak ada kebenaran (sebagai penyebabnya) sehingga ia tidak hidup dalam kebenaran dan ia membunuh manusia (sebagai akibatnya). Kalimat sebab-akibat juga dialami kata-kata selanjutnya "ia berkata dusta (sebagai akibatnya) karena ia adalah pendusta dan (setara) bapa segala dusta, bahwasanya segala dusta itu berasal dari iblis.

Ayat 45 diawali dengan tetapi (sebagai bentuk kata yang berlawanan atau kontras) dimana mereka tidak mau percaya kepada kebenaran yang dikatakan Yesus. Siapakah yang bisa membuktikan Yesus berbuat dosa (46), ini merupakan ungkapan Yesus, sehingga apabila ( $\varepsilon l)$ "adalah sebuah keadaan" (karena memakai sifat condotional) Yesus mengatakan kebenaran mereka tidak percaya. Apa yang berasal dari Yesus adalah benar adanya karena Ia adalah kebenaran yang hidup. Kemudian Yesus mengucapkan inti dari perkataan-Nya "barangsiapa berasal dari Bapa, kata dari terjemahan bahasa aslinya ( $\varepsilon \kappa)$ sebagai kata depan dengan kasus genetif. Akhirnya timbul hubungan sebab-akibat "karena" kamu tidak berasal dari Allah "maka" kamu tidak mendengarkannya.

secara tata bahasa atau gramatikal, dalam teks ini Yesus mengakui keberadaan orang Yahudi sebagai keturunan Abraham secara jasmani. Namun dalam hal rohani Yesus mencela dan tidak mengakui orang Yahudis ebagai keturuan dari Abraham.

\section{Pendekatan secara Literal}

Dalam penafsiran literal ini membahas tentang beberapa ayat yang berhubungan dengan ekslusifitas Yahudi sebagai "keturunan Abraham". Ayat 37 dalam LAI dituliskan "Aku tahu, bahwa kamu adalah anak Abraham", Living Bible menuliskan "I realize that you are descendents of Abraham" yang berarti: "Aku menyadari kamu itu adalah keturunan dari Abraham." Dari dua sumber ini mengarah kepada pengertian yang sama bahwa Yesus mengetahui dan menyadari bahwa mereka adalah keturunan Abraham. Dalam teks asli juga

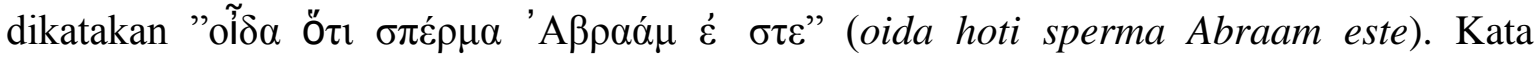
pertama yang akan diselidiki adalah ot $\delta \alpha$ (oida) yang memiliki pengertian "Aku tahu" dengan parsing kata kerja, orang pertama, tunggal, perfek, aktif, indikatif (berarti dari tensis perfek menjelaskan "untuk menunjukkan keadaan sekarang yang diakibatkan oleh sesuatu yang dilakukan pada waktu dahulu/lampau." 36

Kedua, kata $\sigma \pi \varepsilon \rho \mu \alpha$ (sperma) memiliki pengartian "keturunan" dengan parsing kata benda, gender netral, tunggal dan kasus nominatif sedangkan, dalam kamus bahasa indonesia kata keturunan berarti:anak cucu;generasi; angkatan. ${ }^{37}$ Namun

\footnotetext{
${ }^{36}$ Ferdinan K. Suawa, Memahami Gramatika Dasar Bahasa Yunani Koine (Bandung: Yayasan Kalam Hidup, 2009) 35.

${ }^{37}$ Poerwdarminta, Kamus Besar Bahasa Indonesia, 1229.
} 
$A \beta \rho \alpha \alpha \mu$ (Abraam) adalah keterangan orang yang dikenai oleh subjek yang adalah $\varepsilon \sigma \tau \varepsilon$ yaitu orang kedua jamak. Dalam hal ini berarti bahwa orang Yahudi adalah anak cucu atau generasi dari Abraham.

Ayat 39 dalam LAI tertulis, "Bapa kami ialah Abraham." Teks dalam KJV mencatat "Abraham is our father" (Abraham adalah Bapa kami). Kedua sumber ini menerangkan

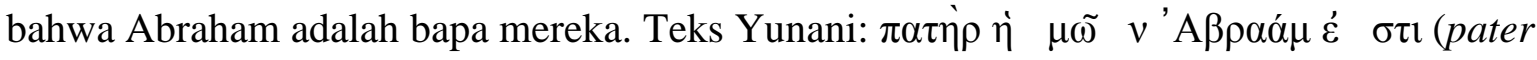
hemon Abraam estin). Kata $\pi \alpha \tau \varepsilon \rho$ diartikan sebagai "nenek moyang" yang juga mengandung pengertian bahwa mereka berasal dari keturunan Abraham.

Ayat 41 mengungkapkan kalimat sebagai pernyataan mereka "Kami tidak dilahirkan dari zinah. Bapa kami satu, yaitu Allah" (LAI). Sedangkan ungkapan dalam terjemahan Alkitab Bahasa Inggris versi Rivised Standard Version, mengatakan bahwa "We were not born out of wedlock, but the father is God himself, yang memiliki pengertian: "kami lahir bukan dari ikatan pernikahan tetapi dari Bapa yang diri-Nya sendiri adalah Tuhan." Dalam

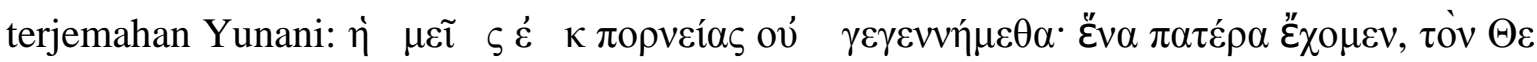
óv (hemeis ek porneias ou gegennemetha. Hena patera ekhomen ton Theon). Kata ov merupakan paritikel, negatif yang berarti suatu kata pengingkaran atau penyangkalan, kata $\gamma \varepsilon \gamma \varepsilon v v \eta \mu \varepsilon \theta \alpha$ memiliki parsing kata kerja, orang pertama, jamak, perfek, pasif, indikatif, yang berasal dari kata $\gamma \varepsilon \gamma \varepsilon v v \eta$ (gegenne) terjemahannya berarti melahirkan. Dalam kasus

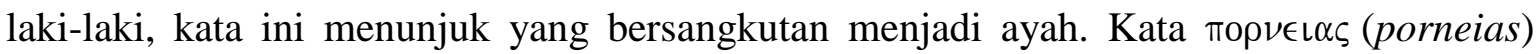
yang berarti "perzinahan" dengan parsing kata benda, feminin, tunggal, genetif, zinah memiliki pengertiandapat menunjuk pemurtadan atau penyembahan. Bahkan dalam kalimat selanjunya mereka menyatakan bahwa " mereka mempunyai satu Bapa, yaitu Allah". Yaitu mengacu kepada Israel secara keseluruhan sebagai umat Allah.

Dari semua penjelasan di atas dimengerti, bahwa secara literal Orang Yahudi adalah keturunan Abraham secara lahiriah saja, tetapi tidak untuk keturunan Abraham secara rohani karena faktanya adalah mereka tidak hidup seperti Abraham bahkan mereka menolak Yesus dan berusaha membunuhNya. Ini berarti bahwa Abraham tidak mewakili mereka dalam hal keselamatan. Orang Yahudi memiliki pemahaman yang salah dalam hal ini. Mereka percaya bahwa Abraham telah berjasa sedemikian besarnya atas kebaikannya, sehingga jsa tersedbut sudah mencukupi, tidak hanya bagi dirinya sendiri, malainkan bagi seluruh keturunannya juga. Menurut orang Yahudi "Kerajaan yang kekal akan diberikan kepada mereka yang berasal dari benih Abraham menurut daging, walaupun mereka adalah orang-orang berdosa, orang-orang yang tidak percaya dan menurut kepada Tuhan." 38 Bahkan orang Yahudi percaya bahwa, secara harfiah dia akan selamat karena dia adalah keturunan dari Abraham.

\footnotetext{
${ }^{38}$ William Barclay. Pemahaman Alkitab Setiap Hari, Injil Yojanes pasal 8:21. (Jakarta: BPK Gunung Mulia,2003), 40 .
} 
Yesus mendapati keturunan Abraham secara lahriah tidak seperti Abraham nenekmoyang mereka. Dalam hal ini Yesus menyatakan bahwa sebenarnya keturunan Abraham yang sesungguhnya adalah orang yang yang bertindak seperti Abraham dahulu bertindak. Bukan seperti yang dilakukan orang Yahudi terhadapNya. Di dalam hal ini khususnya Yesus menekankan pada satu perkara. Mereka berusaha untuk membunuh dia; itulah yang justru bertentangan dengan apa yang dilakukan oleh Abraham. Dalam hal ini menurut Wiliam Barclay:

Pada waktu ia didatangi oleh seorang utusan dari Allah, maka Abraham menyambutnya dengan penuh kesukaan dan hormat (Kej.18:1-9). Abraham telah menyambut baik utusan Allah; akan tetapi orang-orang Yahudi pada masa itu berusaha untuk membunuh utusan Allah. Bagaimanakah mereka dapat menyebut diri keturunan Abraham, jika kelakukan mereka itu berbeda sekali. ${ }^{39}$

Dalam teks yang telah dibahas diatas sangat jelas terlihat betapa pentingnya posisi Abraham bagi mereka sebagai keuturunannya secara lahiriah. Tetapi Yesus mengoreksi kesalahpahaman umum itu dengan menentang mereka. Rumusaan penentuan anak-anak Abraham haruslah beradasarkan moral, bukan berdasarkan jasmani. ${ }^{40}$ Sikap dan tindakan mereka terhadap Yesus sangat tidak sesuai dengan Abraham. Menolak, dan bahkan berusaha untuk membunuh Yesus sangatlah tidak sesaui dengan teladan dari Abraham.

Jadi, sebagai keturunan Abraham secara lahiriah saja tidak cukup untuk menjadi anak Allah. Tetapi keturunan secara rohaniah yang ditunjukan dengan moral yang sesuai itulah yang tepat untuk dikatakan sebagai anak-anak Abraham secara rohani bahkan bisa mengatakan bahwa Allah adala Bapa kami. Walaupun mereka juga mengakui bahwa mereka tidak dilahirkan dari zinah, dan bapa mereka hanya satu yaitu Allah, dalam hal kaitanannya dengan posisi mereka di Perjanjian Lama sebagai umat Allah tetapi Yesus dalam perjanjian Baru terutama di teks ini Yesus tidak menerima mereka sebagai anakanak Allah. Karena mereka tidak hidup seperti anak-anak Allah.

Tafsiran Masa Kini mengatakan bahwa sekali lagi sikap orang terhadap Yesus dijadikan batu ujian. Ia mengatakan kebenaran, karena itu seluruh yang bertentangan dengan Dia tentu palsu. ${ }^{41}$ Hal ini benar, sebab bagaimana mungkin mereka mengatakan Allah adalah Bapa kami, tanpa menerima Yesus sebaga Anak Allah, utusan Allah, dan bahkan adalah Allah sendiri. Derek Prince, dalam bukunya yang berjudul "Dasar Iman", mengatakan bahwa: baik Perjanjian Lama maupun Perjanjian Baru menegaskan kebenaran yang hakikiini: yang harus menjadi dasar utama kehidupan orang Kristen adalah Kristus Sendiri-bukan sesuatu hal atau yang pribadi lainnya. ${ }^{42}$ Ditambahkan pula bahwa, yang harus menjadi dasar bukanlah dogma atau ajarannya, bukan aliran agamanya atau

\footnotetext{
${ }^{39}$ Ibid.,41.

${ }^{40}$ Guthrie, Tafsiran Masa Kini., 296.

${ }^{41}$ Ibid., 297.

${ }^{42}$ Derek Prince. Dasar Iman. (Jakarta: Yayasan Pekabaran Injil Imanuel, 1994), 11.
} 
denominasi gerejanya, bukan pula peraturan agama atau upacaranya. Dasarnya harus Yesus Kristus sendiri. $^{43}$

Jadi dasar yang kuat bukan terletak pada latar belakang keurunan seperti Yahudi yang berpatokan pada Abraham secara lahiriah. Tetapi yang penting adalah keturunan Abraham secara rohani, dalam hal ini adalah percaya dan menerima Yesus secara pribadi serta menerapakn ajaran-ajaran Kristus dalam kehidupan sehari-hari.

\section{Kesimpulan}

Dalam perbandingan antara eksklusivisme Yahudi dan orang Kristen Nominal, maka dapat diambil kesimpulan bahwa, kedua bagian ini memiliki kesamaan. Paham eksklusivisme Yahudi mengatakan bahwa mereka bisa selamat oleh mereka adalah keturunan Abraham, mereka tidak membutuhkan Yesus. Sama halnya dengan orang-orang Kristen Nominal, yang memiliki pemahaman bahwa mereka sudah pasti selamat oleh karena berasal dari keluarga Kristen. Dalam hal ini berarti bahwa mereka tidak harus menerima Yesus Kristus sebagai Tuhan dan Juruselamat secara pribadi untuk keselmatan, karena keselamatan adalah warisan yang diturunkan dari nenek moyang mereka yang juga Kristen. Pemahaman seperti ini menyebabkan orang-orang Kristen nominal memiliki cara hidup yang tidak bertanggung jawab terhadap Firman Tuhan bahkan bertentangan dengan kebenaran yang diajarkan oleh Yesus. Bagi orang Kristen Nominal agama hanyalah tradisi yang telah dianut dari waktu ke waktu oleh nenek moyang, sehingga nilai-nilai dari kepercyaan itu tidak begitu penting pengaruhnya.

Kedua pemahan ini tentunya sangat bertentangan dengan Firaman Tuhan, bahkan dapat menyesatkan. Sebab tidak ada satu bagian dari Firman Tuhan yang mendukung pemahaman-pemahaman seperti itu, karena hanya ada satu jalan untuk selamat yaitu melaui Yesus Kristus, Hanya Yesus dasar yang kuat dan satu-satunya bagi keselamatan, dan untuk selamat setiap orang secara pribadi harus menerima Tuhan Yesus sebagai Tuhan dan Juruselamatnya, serta menghasilakn buah-buah dari pertobatan. Tanpa semuanya itu maka segala usaha dan keyakinan adalah kesia-siaan belaka.

\section{Referensi}

Alkitab, Lembaga Alkitab Indonesia, Jakarta 2002

Alkitab Penuntun Hidup Berkelimpahan, Gandum Mas, Malang 2004

Barclay, William. Pemahaman Alkitab Setiap Hari, Injil Yohanes, BPK Gunung Mulia, 2003.

Ensiklopedi Alkitab Masa Kini, Jilid II M-Z,: Yayasan Komonikasi Bina Kasih/OMF, Jakarta 1996

Poerwadarminta, J. Kamus Besar Bahasa Indonesia, Balai Pustaka, Jakarta 1983.

Kepercayaan dan Kehidupan Kristen, BPK Gunung Mulia, Jakarta, 1985

Pola Hidup Kristen, Penerapan Praktis, Kalam Hidup, Bandung; Yakin, Surabaya;

Gandum Mas, Malang, 1989.

\footnotetext{
${ }^{43}$ Ibid. 11-12
} 
Guthrie, Donald. Tafsiran Alkitab Masa Kini3 Maitus-Wahyu,: BPK Gunung Mulia, Jakarta 1982

Downey, Murray W.Cara-cara Memenagkan Jiwa,Kalam Hidup, Bandung 1975.

Erickson, Millard J.Teologia Kristen, Volume Tiga, Gandum Mas, Malang 2004.

Halim, Makmur. Model - model Penginjilan Yesus, Gandum Mas, Malang, 2003.

Prince Derek, Dasar Iman Seri I, Yayasan Pekabaran Injil,Imanuel, Jakarta 1994.

Robby \& Butler, Jackie. Be A Part Of It, USA: Center For World Mission, 1996

Rumbi, Frans Paillin. “Tradisi Massuru ' Dan Pertobatan Dalam Injil Sinoptik.” BIA:

Jurnal Teologi dan Pendidikan Kristen Kontekstual 1, no. 1 (2018): 26-38.

http://www.jurnalbia.com/index.php/bia.

Suawa, Ferdinan K. Memahami Gramatika Dasar Bahasa Yunani Koine, Bandung: Yayasan Kalam Hidup, 2009

Tume J. Clyder, pokok - pokok Kepercayaan Kristen, Lembaga Literatus Baptis, Bandung 1978.

Weems Loveth H., JR, Pesan John Wesley Masa Kini,Gereja Methodist Indonesia, Medan 1997.

www.persecution.com.

http://www.sabdaspace.org/dua_sisi_keselamatan_kristen_reformed_sejati_adalah 